\title{
Reading the record of magma degassing from gypsum precipitates
}

KIM BERLO ${ }^{1}$, VINCENT VAN HINSBERG ${ }^{1}$, PROF. DANIELE L. PINTI, PHD $^{2}$, BASSAM GHALEB ${ }^{2}$ AND ROMAIN LAUZERAL ${ }^{1}$

${ }^{1}$ McGill University

${ }^{2}$ Université du Québec à Montréal

Presenting Author: olrebmik@gmail.com

Precipitates can be used as a record of changes in fluid chemistry. At Kawah Ijen, Indonesia, gypsum precipitates where effluent from the crater lake and hydrothermal system appear from the rocks. Both the crater lake and the hydrothermal system receive an input from the underlying, active magmatic system. The compositional change in these fluids has been linked to changes in fluid sources including from the magmatic system.

The gypsum precipitates at Kawah Ijen form a plateau with growth layered gypsum. Historical records suggest that the gypsum plateau postdates the last eruption in 1817, although gypsum is also present in the 1817 deposits. The gypsum crystallises in little pools which are transiently interconnected. We use ${ }^{210} \mathrm{~Pb}$ to date these precipitates. The ${ }^{210} \mathrm{~Pb}$ is unsupported and incorporated as $\mathrm{Pb}$. The ${ }^{210} \mathrm{~Pb} / \mathrm{Pb}$ ratio is not constant suggesting that some of the ${ }^{210} \mathrm{~Pb}$ derives from ${ }^{222} \mathrm{Rn}$ and is ultimately derived from volcanic gas. The lake fluid is highly enriched in ${ }^{210} \mathrm{~Pb}$ as a result $\mathrm{f}$ a combination of $\mathrm{Rn}$ degassing and barite precipitation which preferentially captures the $\mathrm{Ra}$. In dating the gypsum we take into account the variation in ${ }^{222} \mathrm{Rn}$ by correlating this with noble gas analyses of the gypsum. This also provides us with a record of the changes in gas flux. Our samples of the gypsum plateau provide us with a record of 100 years over which the growth rate was nearly linear.

The gypsum plateau thus provides a record of chemical change in the fluids including volcanic gas fluctuations. Detailed LIBSICP-MS traverses and SEM reveal that the gypsum contains different types of inclusions: fluid inclusions, barite, syngenite, alunite, sulphides and rock fragments. In addition, there are compositional changes of the gypsum itself, which have been linked to the different inputs into the fluid. This contribution presents a record of fluid change over 100 years. 